\title{
Diagnosis of Simplex Herpes using Case-Based Reasoning Method
}

\author{
Hari Marfalino ${ }^{1}$ \\ UPI YPTK Padang \\ Padang, Indonesia \\ hari.marfalino@upiyptk.ac.id
}

\author{
Dinda Djesmedi \\ UPI YPTK Padang \\ Padang, Indonesia \\ dindadjesmedi@upiyptk.ac.id
}

\author{
Afandi Iddil Filresi ${ }^{3}$ \\ UPI YPTK Padang \\ Padang, Indonesia \\ afandyiddil@gmail.com
}

\begin{abstract}
Artificial Intelligence (AI) is defined as intelligence shown by artificial entities. Such systems are generally considered computers. Intelligence is created and incorporated into a machine (computer) so that it can work like humans. Artificial Intelligence (AI) is defined as intelligence shown by artificial entities. Such systems are generally considered computers. Intelligence is created and incorporated into a machine (computer) so that it can work like humans. CBR method is a method used to solve problems by using previous experience to solve new problems. This research will discuss about Herpes Simplex, venereal disease. In implementing this expert system, it is used by families of patients with Herpes Simplex. The goal is that the expert system can help the patient's family in the initial diagnosis process to determine the symptoms felt by patients with Herpes Simplex. To overcome the above problem, this research will build an expert system using the CBR method by transferring the expertise of doctors into a computing-based system with the results of testing accuracy of $85-90 \%$. With this expert system can help someone find out the type of disease so that they get treatment quickly and accurately.
\end{abstract}

Keywords - Expert System, Case Based Reasoning, Herpes Simplex

\section{INTRODUCTION}

Artificial Intelligence (Artificial Intelligence or AI) is defined as the intelligence shown by an artificial entity. Such systems are generally considered computers. Intelligence is created and incorporated into a machine (computer) so that it can do work as humans can. Artificial Intelligence (Artificial Intelligence or AI) is defined as intelligence shown by an artificial entity. Such systems are generally considered computers. Intelligence is created and incorporated into a machine (computer) so that it can do work like humans can. Some types of fields that use artificial intelligence include expert systems, computer games (games), fuzzy logic, artificial neural networks and robotics (Nasution, 2012).

CBR method is a method used to solve a problem by using previous experience which will later be used to solve a new problem by taking into account the similarity between one with several variables solving from previous problems and the construction of a database system to store revisions to a new problem solution (Pahlawan \& Wibisono, 2017).

This research will discuss about Herpes Simplex, a venereal disease. This disease is characterized by the appearance of group nodules like grapes filled with water and very painful to the genitals (especially when broken and at the first time), and leaves a dry wound and is able to disappear on its own after breaking, approximately for 2 days to 3 weeks. Apart from around the genitals, these nodules can also appear around the anus and mouth.

This disease can recur again. Especially for 1 year after being infected. Fortunately, the symptoms of being infected a second time will not be as painful as the first time and although this virus will continue to persist in your body, the amount of symptoms will decrease with time.

In implementing this expert system, it is used by families of patients with Herpes Simplex. The goal is that the expert system can assist the patient's family in conducting the initial diagnosis process to determine the symptoms felt by sufferers of Herpes Simplex. And with the existence of this expert system can carry out appropriate treatment by sufferers of Herpes Simplex. 


\section{LITERATUREREVIEW}

A. Understanding the System

The system is an order (integrated) consisting of a number of functional components that have certain functions and tasks and are interconnected together aiming to fulfill a particular process (Farthansyah, 2015).

The system is also a collection of elements that are interconnected and work together to carry out the activities indicated to the system and process the input to produce the desired outputs (Krisdianto, 2018).

\section{B. Expert System}

The expert system is one branch of AI that makes extensive use of knowledge specifically for problem solving. An expert is a person who has expertise in a particular field, that is an expert who has knowledge or special abilities that others do not know or are capable of in his field. When the expert system was first developed around the $70 \mathrm{~s}$ the expert system only contained knowledge. However, now the term expert system has been used for various systems that use expert system technology (Listiyanto, 2008).

\section{A. Case Based Reasoning (CBR)}

Case-based reasoning (CBR) uses an artificial intelligence approach (Artificial Intelegent) that focuses on problem solving based on knowledge from previous cases.

In detail CBR is divided into four stages, namely:

1. Retrieve that is rediscovering cases that are most similar to new cases to be evaluated.

2. Reuse is to reuse information or knowledge that has been stored on a case basis to solve new problems.

3. Revise, namely improving the proposed solution.

4. Retain is storing knowledge that will later be used to solve problems on an existing case basis. (Akmal \& Winiarti, 2014).

\section{B. Herpes Simplex disease}

Herpes simplex virus (HSV) infection can be an abnormality in the orolabial region or herpes orolabialis and the genital and surrounding areas or genital herpes, with the typical symptoms of grouping vesicles on the basis of erythematous macules. 1 Genital herpes simplex is one of the sexually transmitted infections (STIs) which is the most frequent problem because it is difficult to cure, often recurs (recurring), also because the transmission of this disease can occur in someone without symptoms or asymptomatic. 1,2 The word herpes can be interpreted as crawling or advancing (creep or crawl) to show the pattern of spread of skin lesions with genital herpes simplex infection.2 World Health Organization (WHO) data estimated that the ages of 15-
49 years living with HSV-2 infection worldwide in 2003 were 536 million. (Bonita \& Murtiastutik, 2017).

C. Causes of Herpes Simplex according to Dr. Qaira Anum,SP,KK (K) :

1. Herpes Simplex ( Hepers Oral )

a. Starting with fever, muscle aches, and weakness.

b. Appears pain, itching, burning or stabbing at the site of infection.

c. Then a blister appears, which is a skin lesion such as a blister that breaks and dries in a few days.

d. The broken blister results in painful sores. If it occurs in the mouth, it can interfere with eating.

2. Herpes Simplex (Herpes Genital)

a. Itchy.

b. Pain when urinating.

c. Fluid discharge from the vagina.

d. The appearance of a lump in the groin.

e. The appearance of painful sores on the genitals, buttocks, anus, or thighs.

D. Solution of Herpes Simplex according to Dr.QairaAnum,SP,KK (K) :

1. Herpes Simplex Virus Tipe 1 ( Hepers Oral)

a. Wash your hands with soap and warm water, especially after using the toilet.

b. Keep skin clean and blistered parts dry. Avoid shaving the infected skin area.

c. Be aware that kissing or oral sex can spread the disease.

d. Learn how to detect early symptoms. Having antiretroviral therapy as early as possible reduces the duration of the disease.

2. Herpes Simplex Virus Tipe 2 (Herpes Genital)

a. Take herpes medicine given by the doctor according to instructions.

b. Keep your herpes dry and clean.

c. Don't touch herpes sores. You should wash your hands often to prevent transmission to other people or other body parts.

d. If you are pregnant, tell your doctor to find out how to protect your baby.

\section{Proposed Method}

\section{A. Data analysis}

The data analysis stage is the most important stage in the development of a system. Data analysis aims to limit the subject and object to be examined in order to become a more systematic and easy to understand information. To obtain data or information 
in this study, the authors first conduct data collection activities that are useful as a support for determining the object of research.

The following classification levels of Herpes Simplex can be seen in the following table :

Table I.Herpes Simplex Classification Data

\begin{tabular}{|c|c|}
\hline $\begin{array}{c}\text { Classificati } \\
\text { on Code }\end{array}$ & Disease Name \\
\hline P001 & $\begin{array}{c}\text { Herpes Simplex Virus Tipe 1 ( } \\
\text { Hepers Oral ) }\end{array}$ \\
\hline P002 & $\begin{array}{c}\text { Herpes Simplex Virus Tipe 2 } \\
\text { (Herpes Genital) }\end{array}$ \\
\hline
\end{tabular}

Source: Dr.QairaAnum, SP.KK

Symptom data for each Herpes Simplex disease can be seen in the following table:

Table II.Symptoms of Herpes Simplex

\begin{tabular}{|c|c|}
\hline $\begin{array}{l}\text { Symptoms } \\
\text { Code }\end{array}$ & Symptoms name \\
\hline G01 & Fever \\
\hline G02 & $\begin{array}{l}\text { The appearance of painful sores } \\
\text { on the genitals in the form of } \\
\text { blisters }\end{array}$ \\
\hline G03 & Feeling weak \\
\hline G04 & $\begin{array}{l}\text { Burning sensation around the } \\
\text { mouth }\end{array}$ \\
\hline G05 & Itching \\
\hline G06 & A lump in the thigh appears \\
\hline G07 & Pain appears \\
\hline G08 & Blisters arise in the mouth area \\
\hline G09 & muscle ache \\
\hline G10 & Pain when urinating \\
\hline G11 & $\begin{array}{c}\text { A broken blister results in injury } \\
\text { and pain }\end{array}$ \\
\hline G12 & $\begin{array}{l}\text { The feeling of being stabbed at } \\
\text { the site of infection }\end{array}$ \\
\hline G13 & discharge from the genitals \\
\hline
\end{tabular}

Source: Dr.QairaAnum, SP.KK

\section{B. Process Analysis}

Based on interviews with experts that the grouping of symptoms can be divided into two, namely:

a. Classification of mild symptoms with weight parameters (w): 1

b. Classification of mild symptoms with weight parameters $(\mathrm{w}): 3$ c. Severe symptom grouping with parameter weight (w): 5

Table III. symptoms and weight of Herpes Simplex

\begin{tabular}{|c|c|c|c|c|}
\hline \multirow{2}{*}{$\begin{array}{l}\text { Symp } \\
\text { tom } \\
\text { Code }\end{array}$} & \multirow{2}{*}{$\begin{array}{c}\text { Name } \\
\text { Symptoms }\end{array}$} & \multicolumn{2}{|c|}{$\begin{array}{l}\text { Disease } \\
\text { code }\end{array}$} & \multirow{2}{*}{$\begin{array}{l}\text { Weight } \\
\text { The } \\
\text { sympto } \\
\text { ms }\end{array}$} \\
\hline & & P01 & $\mathrm{P} 02$ & \\
\hline G01 & Fever & $\sqrt{ }$ & $\sqrt{ }$ & 1 \\
\hline G02 & $\begin{array}{l}\text { The appearance } \\
\text { of painful sores } \\
\text { on the genitals } \\
\text { in the form of } \\
\text { blisters }\end{array}$ & & $\sqrt{ }$ & 5 \\
\hline G03 & Feeling weak & $\sqrt{ }$ & $\sqrt{ }$ & 1 \\
\hline G04 & $\begin{array}{l}\text { Burning } \\
\text { sensation } \\
\text { around the } \\
\text { mouth }\end{array}$ & $\sqrt{ }$ & & 5 \\
\hline G05 & Itching & $\sqrt{ }$ & $\sqrt{ }$ & 3 \\
\hline G06 & $\begin{array}{l}\text { A lump in the } \\
\text { thigh appears }\end{array}$ & & $\sqrt{ }$ & 3 \\
\hline G07 & Pain appears & $\sqrt{ }$ & $\sqrt{ }$ & 3 \\
\hline G08 & $\begin{array}{l}\text { Blisters arise } \\
\text { in the mouth } \\
\text { area }\end{array}$ & $\sqrt{ }$ & & 5 \\
\hline G09 & muscle ache & $\sqrt{ }$ & $\sqrt{ }$ & 1 \\
\hline G10 & $\begin{array}{l}\text { Pain when } \\
\text { urinating }\end{array}$ & & $\sqrt{ }$ & 5 \\
\hline G11 & $\begin{array}{l}\text { A broken } \\
\text { blister results } \\
\text { in injury and } \\
\text { pain }\end{array}$ & $\sqrt{ }$ & & 5 \\
\hline G12 & $\begin{array}{l}\text { The feeling of } \\
\text { being stabbed } \\
\text { at the site of } \\
\text { infection }\end{array}$ & $\sqrt{ }$ & & 5 \\
\hline G13 & $\begin{array}{l}\text { discharge from } \\
\text { the genitals }\end{array}$ & & $\sqrt{ }$ & 3 \\
\hline
\end{tabular}

Source: Dr.QairaAnum, SP.KK

\section{Case Based Reasoning Method Analysis}

The stages of the process analysis are carried out using the Case Based Reasoning method there are four stages of the process in it, namely retrive, reuse, revise and retain. This system is generally guided by the knowledge base owned by the system itself.

The knowledge base is based on symptoms of cases that have been previously diagnosed by an expert 
and calculated by the degree of similarity with new cases. Based on this level of similarity the system will diagnose herpes simplex based on the classification of the disease.

For example, the following is a user dialogue with an expert system and data on symptoms of herpes simplex in an expert system application :

User dialogue with expert systems :

SP: "Do you have a fever?"

User: "YES"

SP: "Do you feel the appearance of painful sores on the genitals in the form of blisters?"

User: "YES"

SP: "Do You Feel Anxious?"

User: "YES"

SP: "Do you feel a burning sensation around your mouth?"

User: "NO"

SP: "Do you feel itchy?"

User: "YES"

SP: "Do you feel a lump in your thigh?"

User: "YES"

SP: "Do you feel pain?"

User: "NO"

SP: "Do you feel a blister in the mouth area?"

User: "NO"

SP: "Do you feel muscle pain?"

User: "YES"

SP: "Do you feel sick when you urinate?"

User: "YES"

SP: "Do You Feel a Blister That Breaks Result in Sores and Pain?"

User: "NO"

Table IV. New Case

\begin{tabular}{|l|l|c|}
\hline Code & \multicolumn{1}{|c|}{ Symptoms are felt } & Weight \\
\hline G01 & Fever & 1 \\
\hline G02 & $\begin{array}{l}\text { The appearance of } \\
\text { painful sores on the } \\
\text { genitals }\end{array}$ & 5 \\
\hline G03 & blisters & 1 \\
\hline G05 & Feeling weak & 3 \\
\hline G06 & Itching & 3 \\
\hline G09 & $\begin{array}{l}\text { A lump in the thigh } \\
\text { appears }\end{array}$ & 1 \\
\hline G10 & Muscle ache & 5 \\
\hline
\end{tabular}

D. System analysis

At this stage, an analysis is carried out on how the expert system for diagnosing herpes simplex will be designed. Through this system design whether the user can be helped with the problems they are experiencing or the user feels confused and does not understand the information that has been given.

The design of this expert system will be designed in the form of a website. A non-member user can access the system contained in the menu, including the home menu that contains herpes simplex, a menu for how to consult, a registration menu and a login menu that is used to $\log$ into the system. The consultation menu contains the implementation of a consultation of the expert system beforehand must login as a member first. For the admin, there are several menus available, namely the homepage for the admin, the management menu for herpes simplex classification level, the management menu for symptoms of herpes simplex disease, the user consultation data menu, the consultation data menu.

1. Design

The design starts by collecting data and facts that support the design of the system by consulting with experts. Furthermore, the design stage will be divided into model design and interface design. In designing this model, it will use 7 Unified Modeling Language (UML) diagrams to design this expert system model.

\section{Design Model}

The design of the Unified Modeling Language (UML) model in this study is as follows:

\section{Use case diagram}

Use Case Diagrams illustrate how. interaction processes carried out by the actor against the system. Model use case of this application can be seen in the following figure : 


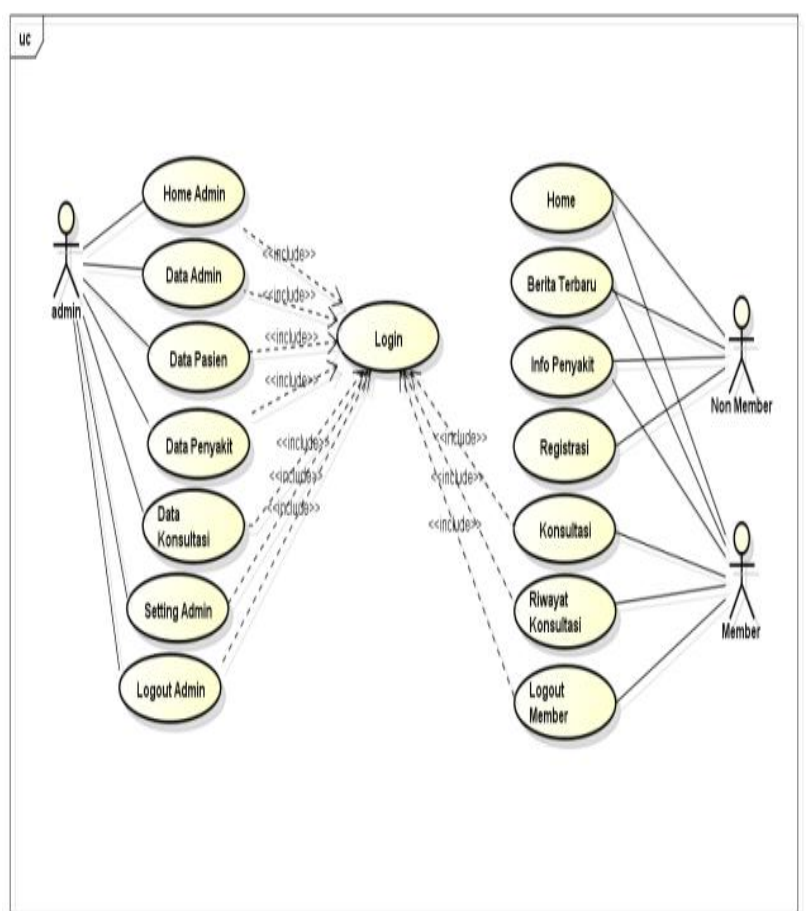

Figure 1. Use Case Diagram

\section{RESULT AND DISCUSSION}

A. Retrieve Process

The retrieve process is the process of finding a resemblance of new cases with existing cases on the knowledge base. Look for similarities is done by matching the symptoms inputted by the user with the symptoms that exist in the knowledge base. In this retrieve process, weighting will be done using the Nearest Neighbor Retrieval algorithm.

At the beginning of the diagnosis process the user will input the symptoms he experienced at once without requiring many questions, then the user will get the results of the diagnosis. The system will do the weighting by matching one by one between the symptoms that are in the knowledge base.

The weight similarity processing stage by the system will be calculated by the following formula :

Similiarity $=\frac{s 1 * w 1+s 2 * w 2+\cdots s n * w n}{w 1+w 2+\cdots w n}$

Keterangan :

$\mathrm{S}=$ similarity (similarity value), the similarity if there is a similarity of cases will be 1, while not similar, it will be 0 .

$\mathrm{W}=$ weight (weight given).
1. Calculation of cases of herpes simplex virus type 1

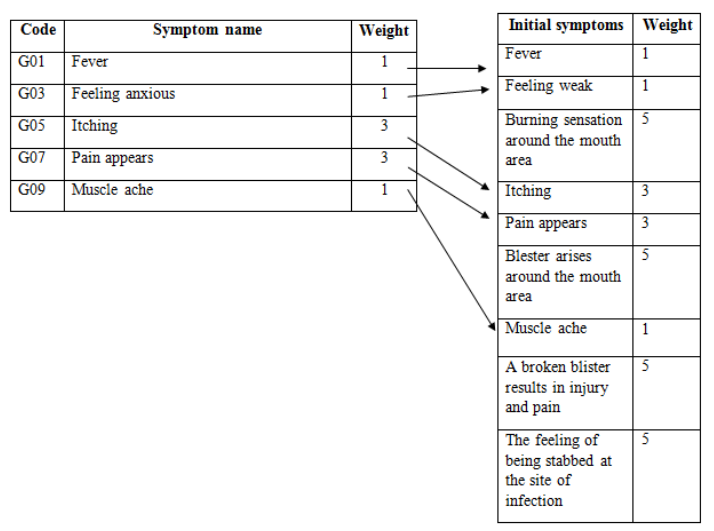

Figure 2. Case herpes simplex type 1 scheme

$$
\text { Similiarity }(x, x)=\frac{s 1 * w 1+s 2 * w 2+\cdots s n * w n}{w 1+w 2+\cdots w n}
$$$$
\frac{(1 * 1)+(1 * 1)+0+(1 * 3)+(1 * 3)+0+(1 * 1)+0+0}{1+1+5+3+3+5+1+5+5}
$$

$$
\begin{aligned}
& =0,51 \\
& =51 \%
\end{aligned}
$$

From the calculation of the case above has a degree of similarity with the old case. so from the similarity calculation of $51 \%$.

2. Calculation of the case for herpes simplex virus type 2

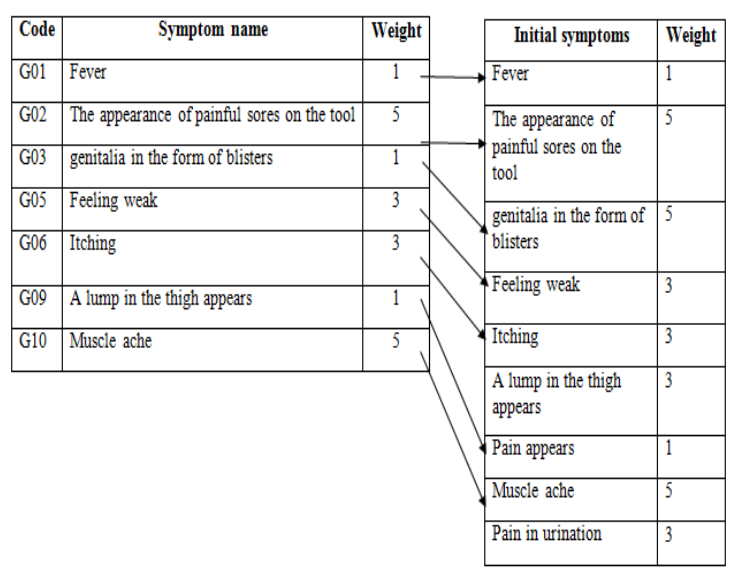

Figure 3. Case herpes simplex type 1 scheme

$\operatorname{Similiarity}(x, x)=\frac{s 1 * w 1+s 2 * w 2+\cdots s n * w n}{w 1+w 2+\cdots w n}$ 
$\frac{(1 * 1)+(1 * 5)+(1 * 1)+(1 * 3)+(1 * 3)+0+(1 * 1)+(1 * 5)+0}{1+5+5+3+3+3+1+5+3}$

$=0.80$

$=80 \%$

the case calculation above has a similarity with the old case. so from the calculation of similarity by $80 \%$.

\section{B. Reuse Process}

Calculation of the case above, the case that has the highest weight similarity with old cases is herpes simplex virus type 2 with a value of $80 \%$

In the reuse process, the solution given is a solution with the highest similarity of existing cases in knowledge with the highest new cases.

\section{Revise Process}

This process is carried out to improve the proposed solution then test it in a real case (simulation) and is needed again to improve the solution to fit the new case.

Computer system security is useful for protecting computers from hacker attacks.

\section{Retain Process}

The retain process is (storing) parts of the experience that might be useful for solving problems in the future.

This process consists of choosing what information from the case to be stored, in what form, how to arrange the case to make it easy to find similar problems, and how to integrate new cases in the memory structure.

When a new problem occurs, the system will first perform a Retrieve process. The Retrieve process will perform two processing steps, namely the introduction of problems and the search for problem equations in the database. After the Retrieve process is complete, the system will then perform the Reuse process. In the Reuse process, the system will use the previous problem information that has similarities to solve new problems. In the Reuse process, it will copy, select and complete the information that will be used. Then in the Revise process, the information will be calculated, evaluated, and corrected again to overcome the errors that occur in new problems. In the last process, the system will do the Retain process. The Retain process will index, integrate, and extract new solutions. Furthermore, the new solution will be stored in a knowledge base to solve future problems. Of course, the problem to be solved is a problem that has something in common with him.

\section{E. System Implementation}

1. Display Home Expert System Skin Disease

The main page display shows the form of the main page of the system when the user accesses the web page. On this main page are displayed home, diagnoses, disease info, news, consultation instructions. The main page display for all users can be seen as Figure :

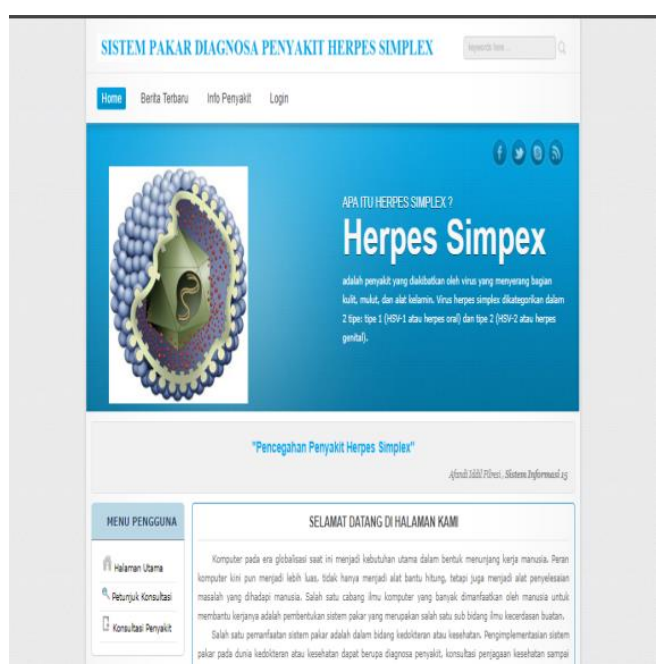

Figure 4. Display Home

2. Consultation Form

In the Consultation Form view, patients can see the consultation instructions before carrying out the process of diagnosing the disease, so that it appears as Figure :

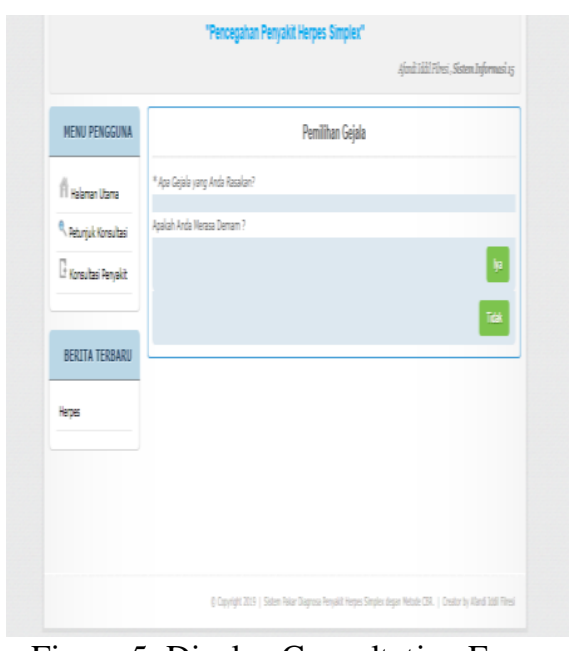

Figure 5. Display Consultation Form

3. Display Consultation Description Form In the consultation statement display on 
the patient, displaying questions that have been answered by the patient, so that it appears as Figure :

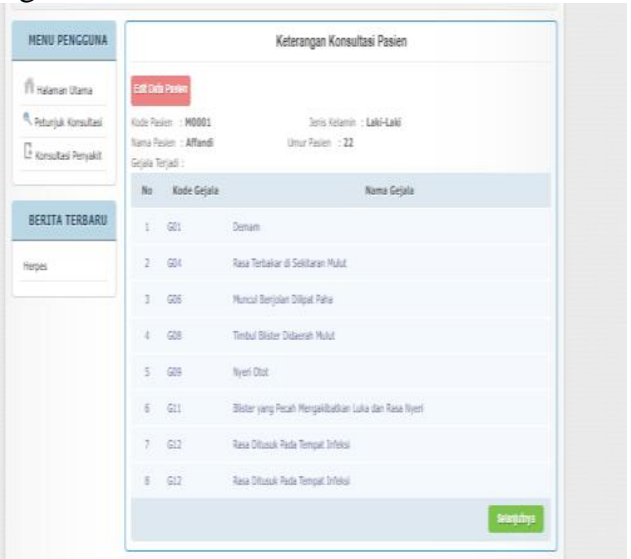

Figure 6. Display Consultation Description Form

4. Display of Consultation Weight Results

In the display of the results of the weights on the patient, displaying the weight of the diagnosis on the patient, so that it appears as Figure :

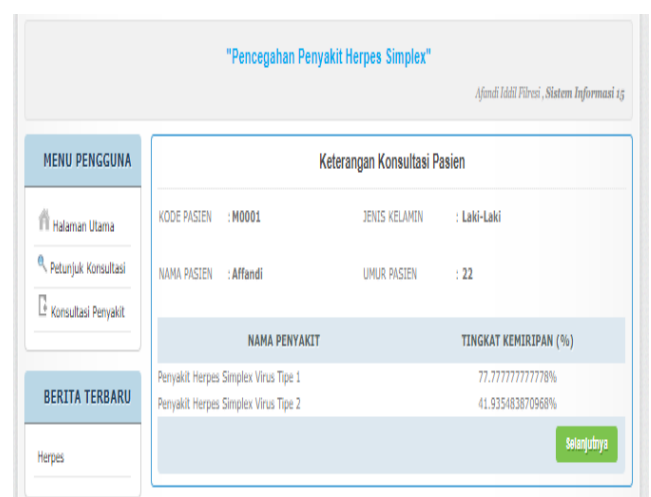

Figure 7. Display of Consultation Weight Results

5. Display of Consultation Results

In the consultation display, displays the results of a diagnostic consultation on the patient, so that it looks like Figure:

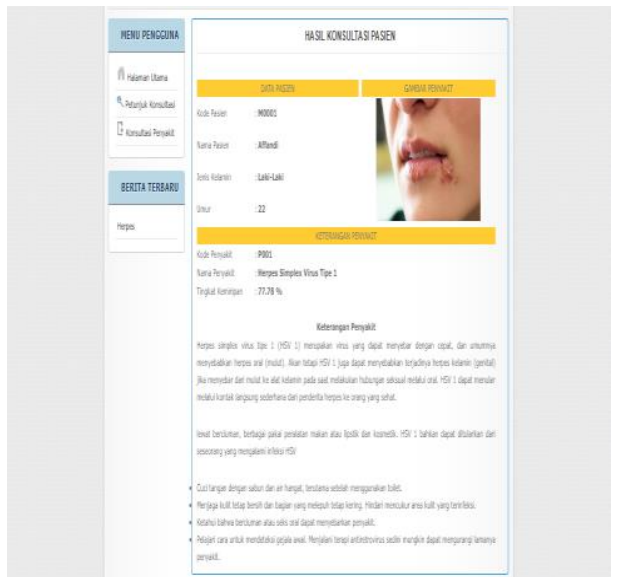

Figure 8. Display of Consultation Results

\section{Conclusion}

Based on the discussion of the previous chapters, conclusions can be drawn regarding the hypothesis, namely:

1. 1. The application of an expert system can help patients make an initial diagnosis of Herpes Simplex. By testing the patient, by selecting the symptoms that exist, it can produce the results of the initial diagnosis of Herpes Simplex by using the PHP programming language and the MySQL database.

2. 2. The design of expert systems using the Casebased reasoning method can be implemented in PHP programming and MySql databases to diagnose Herpes Simplex.

3. 3. The application of an expert system can provide a solution to Herpes Simplex and provide a quick and accurate initial diagnosis based on the expert system's output. 


\section{DAFTAR PUSTAKA}

Akmal.FdanWiniarti.S. (2014). "Sistem Pakar Untuk Mendiagnosa Penyakit Lambung Dengan Metode Case Base Reasoning Berbasis Web”.Jurnal Sarjana Informatika, Vol.2 No.1, Hal 790-800.

Bonita.S dan Murtiastutik.D. (2017). "Gambaran Klinis Herpes Simpleks Genital”.Jurnal Periodical of Dermatology, Vol.29 No.1, Hal 30-35.

Farthansyah. (2015)."Basis Data Revisi Kedua", Bandung : Informatika.

Handayani.S, Anofrizen, dan Jazman.M. (2016). "Sistem Informasi E-Commerce untuk Jaringan Penjualan Pada Sepeda Motor Bekas Kabupaten Kampir'.Jurnal Rekayasa dan Sistem Informasi Informasi, Vol.2 No.2, Hal 106-111.

Kristanto.A. (2018). "Perancangan Sistem Informasi dan Aplikasinya”, Yogyakarta :Gava Media.

Listiyono.H. (2008).“Merancangdan Membuat Sistem Pakar".Jurnal Teknologi Informasi Dinamik, Vol.13 No.2, Hal 115-124.

Minarni,Warman.I,\&Handayani.W. (2017). "Pada Sistem Pakar Identifikasi Hama dan Penyakit Tanaman Singkong Dalam Usaha Meningkatkan Produktivitas Tanaman Pangan”.Jurnal Teknoif, Vol.5 No.1, Hal 4147.

Nasution.H. (2012). “Implementasi Logika Fuzzy pada Sistem Kecerdasa nBuatan”.Jurnal Elkha, Vol.4 No.2, Hal 4-8.

Nugroho.F.E. (2016)."Perancangan Sistem Informasi Penjualan Online Studi Kasus Tokoku”.Jurnal Simetris, Vol.7 No.2, Hal 717-724.

Prasetyo.A. dan Susanti.R (2016). "Sistem Penjualan Berbasis Web Pada PT. Cahaya Sejahtera Sentosa Blitar”.Jurnal Ilmiah Teknologi dan Informasi, Vol.10 No.2, Hal 1-16.

Pahlawan.A.RdanWibisono.S.

"Implementasi Case Based Reasoning Untuk Sistem Diagnosis Hama dan Penyakit Tanaman Cabe Merah Menggunakan Algoritma Similaritas Neyman”. Prosiding Sintak Hal 155-162.

Prabowo.F.A. danSyani.M.(2016). "Sistem informasi Pengolahan Sertifikat Berbasis Web Divisi Training Seamlec".Jurnal Masyarakat Informatika Indonesia, Vol.2 No.1, Hal 73-81.
Rosa.A.S dan Shalahuddin.M. (2018).

"Rekayasa Perangkat Lunak Tersrtruktur dan Berorientasi Objek”, Bandung : Informatika. Sidik.B. (2017). "Pemograman Web Dengan PHP 7’,Bandung :Informatika. 